Article

\title{
Empirical Evidence on Environmental Performance and Operating Costs
}

\author{
Christian Dreyer, Nadja Guenster * and Jakob Koegst \\ Finance Center Muenster, University of Muenster, Universitaetsstr, 14-16, 48143 Muenster, Germany \\ * Correspondence: nadja.guenster@wiwi.uni-muenster.de; Tel.: +49-251-8321886
}

Received: 8 May 2019; Accepted: 24 June 2019; Published: 30 June 2019

\begin{abstract}
Theoretical arguments suggest that better environmental performance can lead to cost advantages through a more efficient use of resources and higher labor productivity. To provide empirical support for these arguments, we investigate how environmental performance affects operating costs using a sample of 785 U.S. firms for the period 2006-2014. We find that better environmental performance is negatively associated with direct production costs, but increases overhead costs. Because direct production costs have a larger impact than overhead costs, aggregate operating costs decline as environmental performance improves. To deal with endogeneity and to interpret the results causally, we use an instrumental variables approach.
\end{abstract}

Keywords: environmental performance; natural-resource-based view; operating costs; overhead costs; production costs; environmental management systems; resource efficiency

\section{Introduction}

The link between environmental performance and financial performance at the firm level is an often discussed topic among economists [1-4]. Many empirical papers show a positive relation between environmental performance and profitability [5-12]. While aggregate profitability measures are used in the empirical implementation, the underlying theoretical argumentation points towards effects of environmental performance on revenues and costs. In the natural-resource-based view, a cost decreasing effect of environmental performance is motivated with the resource efficiency argument $[8,13]$. Following that argument, environmental performance can be increased through more efficient processes, which are accompanied by a reduction in input factors and better waste management [13-15]. In addition, better environmental performance can help firms to attract highly skilled employees and increase labor productivity $[12,16]$. Empirical evidence on the environmental performance-cost link is scarce. A number of case studies examine specific companies and generally point to a negative effect of environmental performance on costs [13,15,17]. Christmann [18] provides survey evidence on firms from the chemical industry. The survey results suggest that the use of pollution prevention technologies is not associated with cost advantages, but the development of proprietary pollution prevention technologies can lead to a cost advantage. Yet, to our knowledge, there is no large sample empirical evidence on the relation between environmental performance and costs. However, this topic is also from a practical perspective of special importance because many executives do not consider the cost decreasing effect of environmental performance improvements in their investment decisions. The McKinsey Global Survey [19] results reveal that only $26 \%$ of the executives name cost cutting as a factor why companies address sustainability. Our findings, however, show that these investments are actually associated with lower operating costs.

We examine the link between environmental performance and operating costs. We split operating costs into overhead costs and direct production costs, and separately investigate both types of costs and their link to environmental performance. We expect a positive relation between environmental 
performance and overhead costs, for example, due to the installation of environmental managements systems $[20,21]$. In contrast, for direct production costs we hypothesize a negative relation by referring to the resource efficiency argument [13-15]. In this line of literature, pollution is seen as an inefficiency in the production process. For example, the use of recycled materials could not only benefit the environment, but also decrease production cost [22]. Similarly, Christman [18] points out a reduction in input costs through a more efficient use of resources, which is at the same time associated with the prevention of environmental pollution.

In our empirical analysis, we use the environmental score provided by Asset4. The Asset4 environmental score comprises the three areas emission reduction, product innovation and resource reduction. Our dataset consists of 4493 firm-year observations of large U.S. companies in the time period 2006-2014. We find that firms with a higher level of environmental performance have significantly lower direct production costs. In contrast, for overhead costs, our results show a positive link: better environmental performance is associated with higher overhead costs. The aggregate effect of environmental performance on operating costs is again negative, because direct production costs account for $78 \%$ of operating costs.

An important concern in studying the relation between environmental and financial performance is the direction of causality. Potentially, firms, which face lower costs have slack resources to invest in improving their environmental performance [23]. To interpret the results causally, we use an instrumental variable approach. Di Giuli and Kostovetsky [24] show that the political environment influences the corporate social responsibility of a firm. We use U.S. election results of the state, where the company's headquarter is located, as an instrument for the environmental performance of the respective company. The results of the instrumental variable approach confirm our previous findings. Our results are robust to different instrumental variable estimation techniques.

This paper makes three contributions. First, we provide empirical evidence for the theoretical arguments that environmental performance can decrease costs. Second, we document a differential effect on different types of costs: while better environmental performance leads to lower operating costs, it is associated with higher overhead costs. Third, we deal with potential reverse causality problems by using an instrumental variable approach. These insights are not only academically relevant, but also important for managers to reach informed decisions on investments in environmental performance.

In Section 2, we discuss the theory and derive hypotheses. Section 3 provides details on our measures of environmental performance, operating costs and the control variables. The results of the empirical analysis are shown in Section 4. Section 5 concludes.

\section{Theory and Hypotheses}

\subsection{Environmental Performance and Direct Production Costs: A Natural-Resource-Based Perspective}

In his seminal work, Hart [13] extends the resource-based view of the firm [25] to include the natural environment. In line with earlier work by Shrivastava and Hart [22], Hart [13] highlights that pollution can be caused by inefficiencies in the production process. A higher level of resource efficiency can lead to lower input and waste management costs [13-15]. By making the production process more efficient, companies can "realize significant savings, resulting in a cost-advantage relative to competitors" [13] (p. 992). Russo and Fouts [12] argue in the same vein and propose that proactive environmental policies, such as the redesign of production and service delivery processes, can result in a better resource efficiency.

Evidence from case studies and survey analyses largely confirms these theoretical arguments. Porter and Kramer [26] argue that innovation, environmental performance, and cost savings go hand in hand. One example they bring forward are enormous cost savings from a reduction in water consumption at companies like Dow Chemical or Coca-Cola. Another example are large cost savings from more efficient packaging and delivery route planning at Wal-Mart. Shrivastava [15] evaluates the environmental technology of the 3M Company. He points out that the innovative 
environmental approaches from $3 \mathrm{M}$ lead to a decrease in costs. These innovative technologies aim to decrease the use of virgin materials and increase the usage of recycled materials in the production process. Nidumolu et al. [17] examine different large US companies and how they achieved better environmental performance (e.g., HP, Wal Mart, FedEx, Cisco, P\&G, Clorox, Waste Management). Nidumolu et al. [17] describe that improvements in environmental performance are a rich source of organizational and technological innovations. They suggest that the reduction in input factors contributes to a decrease in direct production costs. Christman [18] conducts a survey study among managers in the chemical industry. Her results show that managers associate the development of proprietary pollution prevention technology with significant cost advantages.

The work by Russo and Fouts on the natural-resource-based view highlights the role of employees [12]. Russo and Fouts propose that organizations known for environmental stewardship are better able to attract top talent [12]. One reason is that (prospective) employees can better identify themselves with these companies. In line with these assertions, Jones et al. [27] provide evidence that job seekers perceive firms with high environmental standards as more attractive employers. However, the effect of environmental performance is not limited to attracting employees. Employees are a key resource of the firm $[25,28]$ and, as such, they play a central role in implementing better environmental standards [12]. Henrique and Sadorsky [29] use a large cross-country survey to examine the factors influencing firms' environmental performance. Their results show that workers have a positive impact on firms' adoption of environmental management systems. Grolleau et al. [30] argue in the same vein and show that firms aiming for a better human resource management are more likely to implement an environmental management system. Both studies point towards workers' preferences for a higher level of environmental performance. Ambec and Lanoie [31] argue that firms with higher levels of environmental performance can hire more productive and skilled employees. Furthermore, they conjecture that better environmental performance can reduce labor costs by less illness and less personnel turnover. In line with these arguments, Delmas and Pekovic [16] show for a sample of about 5000 French firms that the adoption of a stricter environmental standard is associated with higher levels of labor productivity. To sum up, both the ability to attract top talent, who work more effectively, and the higher labor productivity can lead to a significant decrease in production costs for firms, which have a better environmental performance.

Based on these arguments, we expect that firms can realize significant cost advantages from better environmental performance and hypothesize:

Hypothesis 1. Firms with higher levels of environmental performance have lower direct production costs.

\subsection{Environmental Performance and Overhead Costs}

Few papers discuss the effect of environmental performance on overhead costs. Klassen and Whybark [20] emphasize the need of environmental management systems. These systems include, for example, an environmental department, employee training, and environmental reporting [21]. While such systems might be associated with lower direct production costs from improved resource efficiency and more productive employees, the costs of these systems can increase overhead costs. Darnall and Edwards [32] propose that costs associated with environmental management systems are especially high in the early and adoption stages. They identify costs, such as staff time, external consultants, travel and training, auditors, and certification. These costs are commonly allocated to overhead costs. In a nutshell, the aforementioned arguments point to an increase in overhead costs as the firm improves its environmental performance.

Hypothesis 2. Firms with higher levels of environmental performance have higher overhead costs. 


\section{Data}

\subsection{Environmental Performance}

We use data from Asset4, provided by Thomson Reuters Datastream, to measure the environmental performance of a firm. Asset 4 provides objective, relevant, and auditable environmental, social, and governance information for professional investors. Furthermore, Asset 4 data have been used in several other studies [33-35]. The Asset 4 database covers more than 4600 companies worldwide and generates more than $250 \mathrm{KPI}$ for the ESG performance of every company. Asset4 processes publicly available information, e.g., from company reports, company websites, company filings and NGO websites. In addition to that, Asset 4 considers information from established and trustworthy media.

In our analysis, we concentrate on the overall environmental score. The score is normalized, where 1 is the best and 0 the worst environmental performance. The overall environmental score evaluates the firm's performance in the fields of resource usage, emissions, and emissions reductions. Examples are energy used, $\mathrm{CO}_{2}$ emissions, and waste recycled. Furthermore, environmental activism and product and process innovation are taken into account. The overall environmental score is built upon 53 binary and 17 metric indicators. One example for a metric indicator is greenhouse gas emissions produced by the company. An example for a Boolean indicator is whether the company received an environmental label or award [36].

In unreported robustness tests, we repeat all analyses with the resource reduction score provided by Asset 4 instead of the Asset 4 overall environmental score. The results are very similar.

\subsection{Financial Measures}

Cost measures. We include three different types of costs: direct production, overhead, and operating costs. We use the item "costs of goods sold" from Compustat to measure direct production costs. Costs of goods sold is defined in Compustat as "all costs directly allocated by the company to production, such as material, labor and overhead" [37] (p. 49). We use the item "selling, general and administrative expenses" from Compustat to measure overhead costs. Selling, general, and administrative expenses are the major nonproduction costs and include, among other things, compensation paid to management, accounting expenses, engineering expenses, corporate expenses etc. [37].

We use the item "operating expenses total" from Compustat to measure the overall operating costs. These costs comprise all ongoing costs, which are necessary to run a business. They capture both overhead costs and direct production costs.

Consistent with previous studies, we scale all three types of costs by total assets to obtain a cost measure that is independent of firm size [7-12]. We refrain from using sales volume as a scaling variable, as it is potentially influenced by environmental performance. Russo and Fouts [12] point out that eco-aware customers prefer buying from companies with a high level of environmental performance. Furthermore, many studies provide evidence of a link between environmental performance and price premia [38,39]. Both effects imply a positive correlation between environmental performance and sales. This correlation might have biased our findings, if we had used sales as scaling variable. In unreported robustness tests, we additionally use employees as a scaling variable. These results are qualitatively similar and do not seem to be dependent on the scaling variable.

Control variables. We include the debt-to-assets ratio as a control variable in our analysis. The debt-to-assets ratio is commonly used as a control variable in studies examining firm profitability $[7,9,11]$. Jensen [40] posits that debt exerts discipline on managers, which decreases wasteful spending and increases the investments in profitable opportunities. Ultimately, this effect should decrease the operating costs and we conjecture a negative sign for the debt-to-assets ratio.

The book-to-market ratio is used to control for firms' growth opportunities. Russo and Fouts [12] describe that low-growth firms are more likely to be hierarchical, inflexible, and bureaucratic. Thus, we expect that firms with a high book-to-market ratio face higher costs compared to firms with a low book-to-market ratio. 
We use the natural logarithm of sales volume as a control for firm size. Sales volume is an often used proxy for firm size [7,41,42]. In the context of our analysis, sales volume bears the advantage of accounting for changes in costs that are driven by sales volume. Therefore, we can control for the effect that a change in sales volume has on costs.

\subsection{Descriptive Statistics}

Table 1 shows descriptive statistics for all variables. After merging both databases, our sample consists of 785 U.S. firms and 4493 firm-year observations (except for overhead costs, where we only have 4112 observations). The examined time period ranges from 2006 to 2014 . The means of direct production costs and overhead costs scaled by total assets are 0.53 and 0.18 , respectively. Given the larger magnitude of direct productions costs, they are of greater importance for operating costs.

Table 1. Means, Standard Deviations, Min, Max.

\begin{tabular}{lllll}
\hline Variable & Mean & S.D. & Min & Max \\
\hline Direct production costs (COGS) $^{\mathrm{b}}$ & 0.53 & 0.59 & 0.00 & 4.73 \\
Overhead costs (SGA) $\mathrm{a}, \mathrm{b}^{\mathrm{O}}$ & 0.18 & 0.17 & 0.00 & 1.09 \\
Operating expenses (OPEX) $^{\mathrm{b}}$ & 0.68 & 0.67 & 0.00 & 4.85 \\
Environmental score $^{\text {Debt-to-assets ratio }}$ & 0.44 & 0.32 & 0.09 & 0.97 \\
Book-to-market ratio $_{\text {Sales volume }}^{\mathrm{c}}$ & 0.24 & 0.18 & 0.00 & 0.94 \\
& 0.53 & 0.46 & 0.00 & 8.07 \\
\hline
\end{tabular}

${ }^{\mathrm{a}} \mathrm{N}=4112{ }^{\mathrm{b}}$ Direct production costs, overhead costs, and operating expenses are scaled by the firms' total assets.

${ }^{\mathrm{c}}$ Logarithm of sales.

When examining the year 2014 in our dataset, we find 3M Corporation to be the company with the highest environmental score of 0.9492 . The lowest environmental score assigned to a company by Asset4 was 0.0876 in 2014.

\section{Research Results}

\subsection{OLS Results}

Table 2 reports the results for the pooled OLS estimations. We control for industry effects with industry dummies at the one-digit SIC level. Furthermore, we include year dummies to control for time effects. We use standard errors, which are clustered at the firm level. We believe that pooled OLS is an appropriate way to explore the data, as most of the variation in environmental performance is between and not within-variation. A table with a variance decomposition of environmental performance in between and within variation is shown in the Appendix in Table A5. Furthermore, we are not able to apply any firm-fixed effects in the following instrumental variable regression because our instrumental variable is time-invariant for firms. To confirm the robustness of our findings, we also present the results of different estimation methods in the Appendix A. We present results for firm-fixed effect regressions (Table A1), and cross-sectional regressions (Tables A2-A4).

The results in Table 2 confirm our first hypothesis that environmental performance is negatively associated with direct production costs. The effect is also economically significant. A $10 \%$ increase in the environmental performance of the average firm leads to a decrease in direct production costs of $2.6 \%$ ( The detailed computation is as follows: The mean value of direct production costs is 0.53 and the mean value of environmental performance is 0.44 (see Table 1 ). The coefficient of environmental performance in column (1) in Table 2 is -0.31 . Consequently, a $10 \%$ increase in the environmental score $(10 \% \times 0.44=0.044)$ is associated with a decrease of direct production cost equal to $-0.31 \times 0.044 / 0.53$ $=2.6 \%$ for an average firm. Henceforth, the computation of the economic significance is based on the same principle.). Furthermore, the results show a significant positive relation between overhead costs and environmental performance. This finding confirms our second hypothesis. Again, the effect is also economically significant. A $10 \%$ increase in the environmental performance of the average firm leads 
to an increase in overhead costs of $1 \%$. When considering the effect of environmental performance on operating costs, we find a cost decreasing effect of environmental performance. The effect is also economically significant: a $10 \%$ increase in the environmental performance of the average firm leads to a decrease in operating costs of $1.7 \%$. All coefficients for environmental performance are significant at least at the $5 \%$ level.

Table 2. Pooled OLS Results.

\begin{tabular}{lccc}
\hline Variable & COGS & SGA & OPEX \\
\hline Environmental score & $-0.31^{* * *}$ & $0.04^{* *}$ & $-0.27^{* * *}$ \\
& $(0.07)$ & $(0.02)$ & $(0.07)$ \\
Debt-to-assets ratio & $-0.40^{* * *}$ & $-0.24^{* * *}$ & $-0.61^{* * *}$ \\
& $(0.10)$ & $(0.03)$ & $(0.11)$ \\
Book-to-market ratio & -0.03 & $-0.07^{* * *}$ & $-0.09^{* *}$ \\
& $(0.03)$ & $(0.01)$ & $(0.04)$ \\
Sales volume & $0.18^{* * *}$ & $-0.02^{* * *}$ & $0.16^{* * *}$ \\
& $(0.02)$ & $(0.00)$ & $(0.02)$ \\
Intercept & $-0.86^{* * *}$ & $0.36^{* * *}$ & $-0.50^{* *}$ \\
& $(0.24)$ & $(0.05)$ & $(0.22)$ \\
Industry controls & YES & YES & YES \\
Year dummies & YES & YES & YES \\
Observations & 4493 & 4112 & 4493 \\
R-squared & 0.44 & 0.38 & 0.48 \\
\hline
\end{tabular}

All specifications include industry dummies at the one-digit SIC level and year dummies. Standard errors in parentheses are clustered at the firm-level. Significance is denoted with ${ }^{*} p<0.1,{ }^{* *} p<0.05,{ }^{* * *} p<0.01$ (Two-tailed tests).

The debt-to-assets ratio has a negative relation to all types of costs. This result is in accordance with the idea that debt disciplines the firm's management and prevents managers from wasteful spending [40]. Sales volume is positively associated with direct production costs and operating costs and is negatively associated with overhead costs. The book-to-market ratio is negatively associated with overhead costs and operating expenses. For direct production costs, the effect of the book-to-market ratio is insignificant.

\subsection{Instrumental Variable Results}

One issue that we might face in our analysis is a reverse causation problem [43]. Environmental performance might decrease costs. The other possibility is that firms with low costs have more slack resources, which they can then invest to improve environmental performance [23]. McGuire, Sundgren, and Schneeweis [44] scrutinize relationships between financial performance and corporate social responsibility. Interestingly, they find that prior financial performance is more closely related to corporate social responsibility than subsequent financial performance. In a nutshell, their results reveal that a high level of financial performance leads to a high level of corporate social responsibility in subsequent years. Therefore, the slack resource hypothesis points towards a reverse causation problem. Another potential issue is the omitted variable bias [45]. One important variable, which is missing in our analysis, is management quality. Management quality is hard to measure. However, a good management can increase environmental performance and decrease operating costs [23].

Deng et al. [43] face similar problems when analyzing the financial effect of corporate social responsibility for acquiring firms' shareholders. They apply the instrumental variable approach to deal with this issue and use the political orientation of the state where the firm is headquartered as an instrument. We use a similar methodology as Deng et al. [43] and use the Democratic leaning of a state as an instrument. Our hypothesis is that firms headquartered in a Democratic leaning state have a higher level of environmental performance.

We construct our proxy for the Democratic leaning of a state as our instrumental variable with principal component analysis similar to Di Giuli and Kostovetsky [24]. We incorporate election results 
on the state and national level to get a complete picture of the political orientation. On the state level we use the elections for the Lower and Upper House in the years 2008 and 2011. For the Lower and Upper House, we calculate the Democratic Leaning score as members from the Democratic Party divided by the total number of members for each state (For example: In 2011 Alabama gets a Democratic Leaning Score for the Lower House of 0.38. It has 105 members and 39 of them are Democratic. http://www.ncsl.org/documents/statevote/LegisControl_2011.pdf). On the national level, we take the elections for the House of Representatives in the years 2008 and 2012 and the presidential elections in the years 2008 and 2012 into account. For the House of Representatives elections, we calculate for each state the Democratic Leaning score as seats won by democrats divided by the total number of seats of the respective state (For example: In 2012 Alabama gets a Democratic leaning score for the House of Representatives of 0.14. In 2012 it has 7 seats in the House of Representatives and only 1 out of 7 was a Democrat. https://en.wikipedia.org/wiki/ United_States_House_of_Representatives_elections,_2012\#Alabama). For the presidential elections, we take the percentage votes for the Democrats as our score (For example: In 2012 Alabama gets a Democratic leaning score for the presidential elections of 0.38 because Democrats received $38 \%$ of the votes. https://en.wikipedia.org/wiki/United_States_presidential_election,_2012). Furthermore, we incorporate the Partisan Voter Index, which shows how strongly a state leans toward the Democratic or Republican Party compared to the nation calculated in years 2010 and 2014. We obtain the Partisan Voter Index data for the years 2010 and 2014 from https://www.cookpolitical.com. In the year 2010 and 2014 the District of Columbia was by far the most Democratic leaning state according to the Partisan Voter Index. To get a better overview of the data, we provide descriptive statistics in Table A7. We use all these ten different scores for our principal component analysis. For our further regression analysis, we use the first principal component as our instrument, which explains $77 \%$ of the variation of all political variables.

In the following, we discuss why our instrument fulfills the relevance and exclusion restriction. We argue that the exclusion restriction is fulfilled as the political orientation of the state is not likely to directly influence the operating costs. In order to fulfill the relevance condition, the political orientation of the state, where the firm is headquartered, should be highly correlated with the environmental performance of the firm. Di Giuli and Kostovetsky and Rubin show that the political environment influences the corporate social responsibility of a firm [24,46]. Firms which are headquartered in Democratic-leaning states are accompanied with a higher corporate social responsibility than firms in Republican-leaning states. Our empirical check of the relevance condition shows F-statistics higher than 12 for all regressions where environmental performance is instrumented by the political orientation of the state. Stock et al. [47] suggest a critical F-Value of 8.96 for one instrument. Therefore, our instrumental variable regression is not likely to have a weak instrument problem.

We run a Fuller modified limited-information maximum likelihood estimation because it is more robust than the standard 2SLS technique $[48,49]$. Our results can be confirmed with other specifications such as 2SLS (Table A6). In our regression model, we are only able to apply industry-fixed effects instead of firm-fixed effects because our instrumental variable is time-invariant for each firm in our sample.

The instrumental variable regressions presented in Table 3 show similar results as in the pooled OLS setting. They indicate a decreasing effect of environmental performance on direct production and operating costs and an increasing effect on overhead costs. The coefficients of environmental performance are significant at the $1 \%$ level in each setting. The control variables also point in the expected direction. To sum up, we find a significant influence from environmental performance on all type of costs, which is not likely to be driven by endogeneity or reverse causality. 
Table 3. Instrumental Variable Regression Results.

\begin{tabular}{lcccccc}
\hline Variable & $\begin{array}{c}\text { First Stage } \\
\text { DV=ENV }\end{array}$ & $\begin{array}{c}\text { Model 1: } \\
\text { COGS }\end{array}$ & $\begin{array}{c}\text { First Stage } \\
\text { DV=ENV }\end{array}$ & $\begin{array}{c}\text { Model 2: } \\
\text { SGA }\end{array}$ & $\begin{array}{c}\text { First Stage } \\
\text { DV=ENV }\end{array}$ & $\begin{array}{c}\text { Model 3: } \\
\text { OPEX }\end{array}$ \\
\hline Environmental score & & $-5.47^{* * *}$ & & $0.75^{* * *}$ & & $-4.78^{* * *}$ \\
& & $(1.18)$ & & $(0.19)$ & & $(1.05)$ \\
Democratic leaning & $0.01^{* * *}$ & & $0.01^{* * *}$ & & $0.01^{* * *}$ & \\
& $(0.00)$ & & $(0.00)$ & & $(0.00)$ & \\
Debt-to-assets ratio & 0.01 & $-0.41^{* * *}$ & -0.01 & $-0.22^{* * *}$ & 0.01 & $-0.63^{* * *}$ \\
& $(0.02)$ & $(0.12)$ & $(0.02)$ & $(0.02)$ & $(0.02)$ & $(0.11)$ \\
Book-to-market ratio & $-0.05^{* * *}$ & $-0.29^{* * *}$ & $-0.04^{* * *}$ & $-0.04^{* * *}$ & $-0.05^{* * *}$ & $-0.32^{* * *}$ \\
& $(0.01)$ & $(0.08)$ & $(0.01)$ & $(0.01)$ & $(0.01)$ & $(0.08)$ \\
Sales volume & $0.13^{* * *}$ & $0.84^{* * *}$ & $0.13^{* * *}$ & $-0.11^{* * *}$ & $0.13^{* * *}$ & $0.74^{* * *}$ \\
& $(0.00)$ & $(0.15)$ & $(0.00)$ & $(0.02)$ & $(0.00)$ & $(0.13)$ \\
Industry controls & YES & YES & YES & YES & YES & YES \\
Year dummies & YES & YES & YES & YES & YES & YES \\
Observations & 4461 & 4461 & 4092 & 4092 & 4461 & 4461 \\
F test (instrument, overall) & $12.97^{* * *}$ & $12.14^{* * *}$ & $12.911^{* * *}$ & $19.42^{* * *}$ & $12.97^{* * *}$ & $13.54^{* * *}$ \\
\hline
\end{tabular}

All specifications include industry dummies at the one-digit SIC level and year dummies. Standard errors in parentheses are robust to heteroscedasticity. Significance is denoted with ${ }^{*} p<0.1{ }^{* *} p<0.05,{ }^{* * *} p<0.01$ (Two-tailed tests). Estimation is made with Fuller's modified LIML.

\section{Discussion and Conclusions}

The results show that firms with better environmental performance can benefit from lower operating costs. Overhead costs increase slightly, but this effect is more than outweighed by a sizable decrease in costs of goods sold. Importantly, we do not only find these results in a typical regression model, but also in an instrumental variable setting. Thus, we are reasonably confident to conclude that environmental performance leads to lower operating costs and that our findings are unlikely to be affected by reverse causality or other endogeneity problems.

Our findings provide evidence in favor of theoretical arguments made by proponents of the natural-resource-based view, notably Hart [13] and Russo and Fouts [12]. One important argument of the natural-resource-based view is that pollution prevention is associated with lower costs [50]. We contribute to this line of research by providing empirical evidence on the relation between environmental performance and operating costs. Future research can build on our findings and analyze in more detail which factors moderate the relation between cost and environmental performance and how this relation varies across firms. The relation between environmental performance and costs likely depends on complementary assets and capabilities of the firm [18], and the location of the firm. In her meta-study, Albertini [5] provides evidence that the relation between environmental performance and aggregate accounting and market-based measures of financial performance varies across countries. This finding might be due to differences in the environmental performance-cost relation across countries; for example, different legal settings, input costs, employee preferences, and firm cultures.

The focus of our study on costs allows us to empirically test one specific line of argumentation of the natural-resource-based view: the relation between environmental performance and cost efficiency. However, this advantage can, at the same time, also be seen as a limitation of our work. We ignore many other aspects of the natural-resource-based view in our analysis. For example, the natural-resource-based view suggests that firms can gain a better reputation from high environmental standards [12]. This reputation effect might translate into higher revenues as firms attract loyal customers. This mechanism might be another explanation for the often-reported positive relation between profits and environmental performance. Albuquerque et al. [51] show that product differentiation from high corporate social responsibility standards can lead to customer loyalty and less systematic risk. To our knowledge, there is not yet any work that tests for effects of environmental performance on revenues and the volatility of revenues.

Our study also has important practical contributions. As Dowell and Hart [50] point out, "Managers that search for opportunities to profit via pollution prevention have the potential to find 
such opportunities, but their prior expectations about whether such opportunities exist strongly affects their search." [50] (p. 1469). We hope that our findings persuade and encourage managers to search for cost advantages from environmental opportunities within their firms. The relatively recent McKinsey survey from 2014 [19] shows that still nowadays only about one quarter of managers pursue sustainability initiatives with the goal to cut costs. Thus, there seems to be a lot of unused potential that can be realized by convincing managers of the cost advantages from better environmental performance. From a practical perspective, it would be important for future research to provide more detailed guidance for managers on how to identify and implement improvements in environmental performance that reduce operating costs.

Author Contributions: Conceptualization, N.G. and J.K.; Methodology, J.K. and C.D.; Formal analysis, J.K. and C.D.; Writing-Original Draft Preparation, N.G. and J.K.; Writing-Review \& Editing, C.D. and N.G.

Funding: This research received no external funding.

Acknowledgments: We thank Daniel Brodback, Jeroen Derwall, Stefanie Kleimeier, Oliver Schulz and seminar participants at the Open University Heerlen, the Netherlands, the 2017 AFFI Conference in Valence, France, and the 2017 CRR Conference in Seville, Spain, and the 2018 Annual Academy of Management Meeting, Chicago, $\mathrm{IL}$, for valuable comments and feedback.

Conflicts of Interest: The authors declare no conflict of interest.

\section{Appendix A}

Table A1. Firm-Fixed Effect Regression Results.

\begin{tabular}{llll}
\hline Variable & COGS & SGA & OPEX \\
\hline Environmental score & $-0.08^{* * *}$ & $-0.02^{* *}$ & $-0.09^{* * *}$ \\
& $(0.02)$ & $(0.01)$ & $(0.03)$ \\
Debt-to-assets ratio & $-0.37^{* * *}$ & $-0.05^{* *}$ & $-0.42^{* * *}$ \\
& $(0.12)$ & $(0.02)$ & $(0.14)$ \\
Book-to-market ratio & -0.00 & -0.00 & -0.01 \\
& $(0.01)$ & $(0.00)$ & $(0.01)$ \\
Sales volume & $0.08^{* * *}$ & $-0.01^{*}$ & $0.07^{* * *}$ \\
Intercept & $(0.02)$ & $(0.00)$ & $(0.03)$ \\
& 0.11 & $0.28^{* * *}$ & $0.38^{*}$ \\
Observations & $(0.20)$ & $(0.04)$ & $(0.21)$ \\
R-squared & 4493 & 4112 & 4493 \\
\hline
\end{tabular}

Standard errors in parentheses are robust to heteroscedasticity. Significance is denoted with ${ }^{*} p<0.1, * * p<0.05$, *** $p<0.01$ (Two-tailed tests).

Table A2. Cross-Sectional Regression Results-COGS.

\begin{tabular}{|c|c|c|c|c|c|c|c|c|c|}
\hline Variable & $\begin{array}{l}\text { COGS } \\
2006\end{array}$ & $\begin{array}{l}\text { COGS } \\
2007\end{array}$ & $\begin{array}{l}\text { COGS } \\
2008\end{array}$ & $\begin{array}{l}\text { COGS } \\
2009\end{array}$ & $\begin{array}{l}\text { COGS } \\
2010\end{array}$ & $\begin{array}{l}\text { COGS } \\
2011\end{array}$ & $\begin{array}{l}\text { COGS } \\
2012\end{array}$ & $\begin{array}{l}\text { COGS } \\
2013\end{array}$ & $\begin{array}{l}\text { COGS } \\
2014\end{array}$ \\
\hline Environmental score & $\begin{array}{l}-0.34^{* * *} \\
(0.13)\end{array}$ & $\begin{array}{l}-0.31 \text { ** } \\
(0.13)\end{array}$ & $\begin{array}{l}-0.45^{* * * *} \\
(0.12)\end{array}$ & $\begin{array}{l}-0.40^{* * *} \\
(0.09)\end{array}$ & $\begin{array}{l}-0.32 \text { *** } \\
(0.09)\end{array}$ & $\begin{array}{l}-0.26^{* * *} \\
(0.08)\end{array}$ & $\begin{array}{l}-0.28^{* * *} \\
(0.08)\end{array}$ & $\begin{array}{l}-0.30^{* * *} \\
(0.08)\end{array}$ & $\begin{array}{l}-0.27^{* * *} \\
(0.08)\end{array}$ \\
\hline Debt-to-assets ratio & $\begin{array}{l}-0.63^{* * * *} \\
(0.19)\end{array}$ & $\begin{array}{l}-0.37 * \\
(0.19)\end{array}$ & $\begin{array}{l}-0.45^{* * *} \\
(0.15)\end{array}$ & $\begin{array}{l}-0.39^{* * *} \\
(0.13)\end{array}$ & $\begin{array}{l}-0.31^{* * *} \\
(0.10)\end{array}$ & $\begin{array}{l}-0.36^{* * *} \\
(0.12)\end{array}$ & $\begin{array}{l}-0.41^{* * *} \\
(0.12)\end{array}$ & $\begin{array}{l}-0.39^{* * *} \\
(0.10)\end{array}$ & $\begin{array}{l}-0.39^{* * *} \\
(0.10)\end{array}$ \\
\hline Book-to-market ratio & $\begin{array}{l}-0.43^{\text {**** }} \\
(0.16)\end{array}$ & $\begin{array}{l}-0.22 \text { ** } \\
(0.10)\end{array}$ & $\begin{array}{l}-0.00 \\
(0.03)\end{array}$ & $\begin{array}{l}-0.04 \\
(0.06)\end{array}$ & $\begin{array}{l}-0.08 \\
(0.06)\end{array}$ & $\begin{array}{l}-0.01 \\
(0.04)\end{array}$ & $\begin{array}{l}-0.00 \\
(0.05)\end{array}$ & $\begin{array}{l}-0.04 \\
(0.06)\end{array}$ & $\begin{array}{l}-0.03 \\
(0.03)\end{array}$ \\
\hline Sales volume & $\begin{array}{l}0.22^{* * *} \\
(0.03)\end{array}$ & $\begin{array}{l}0.20^{* * *} \\
(0.03)\end{array}$ & $\begin{array}{l}0.22 \text { *** } \\
(0.03)\end{array}$ & $\begin{array}{l}0.19^{* * * *} \\
(0.02)\end{array}$ & $\begin{array}{l}0.18^{* * *} \\
(0.02)\end{array}$ & $\begin{array}{l}0.19^{* * *} \\
(0.02)\end{array}$ & $\begin{array}{l}0.17^{* * * *} \\
(0.02)\end{array}$ & $\begin{array}{l}0.17^{* * * *} \\
(0.02)\end{array}$ & $\begin{array}{l}0.17^{* * *} \\
(0.02)\end{array}$ \\
\hline Intercept & $\begin{array}{l}-1.21 * * * \\
(0.21)\end{array}$ & $\begin{array}{l}-0.99^{* * *} \\
(0.22)\end{array}$ & $\begin{array}{l}-0.72^{* * *} \\
(0.20)\end{array}$ & $\begin{array}{l}-0.61^{* * *} \\
(0.15)\end{array}$ & $\begin{array}{l}-0.82 * * * \\
(0.25)\end{array}$ & $\begin{array}{l}-0.95^{* * *} \\
(0.27)\end{array}$ & $\begin{array}{l}-0.76^{* * *} \\
(0.26)\end{array}$ & $\begin{array}{l}-0.78^{* * *} \\
(0.26)\end{array}$ & $\begin{array}{l}-0.76^{* * *} \\
(0.25)\end{array}$ \\
\hline Observations & 298 & 315 & 425 & 500 & 578 & 585 & 587 & 595 & 610 \\
\hline R-squared & 0.49 & 0.43 & 0.45 & 0.46 & 0.45 & 0.44 & 0.42 & 0.40 & 0.42 \\
\hline
\end{tabular}

All specifications include industry dummies at the one-digit SIC level. Standard errors in parentheses are robust to heteroscedasticity. Significance is denoted with ${ }^{*} p<0.1{ }^{* *} p<0.05,{ }^{* * *} p<0.01$ (Two-tailed tests). 
Table A3. Cross-Sectional Regression Results-SGA.

\begin{tabular}{lccccccccc}
\hline Variable & SGA & SGA & SGA & SGA & SGA & SGA & SGA & SGA & SGA \\
& $\mathbf{2 0 0 6}$ & $\mathbf{2 0 0 7}$ & $\mathbf{2 0 0 8}$ & $\mathbf{2 0 0 9}$ & $\mathbf{2 0 1 0}$ & $\mathbf{2 0 1 1}$ & $\mathbf{2 0 1 2}$ & $\mathbf{2 0 1 3}$ & $\mathbf{2 0 1 4}$ \\
\hline Environmental score & -0.01 & 0.06 & $0.07^{* * *}$ & $0.05^{*}$ & 0.03 & $0.04^{*}$ & $0.04^{*}$ & $0.03^{*}$ & $0.04^{*}$ \\
& $(0.03)$ & $(0.04)$ & $(0.03)$ & $(0.03)$ & $(0.03)$ & $(0.03)$ & $(0.02)$ & $(0.02)$ & $(0.02)$ \\
Debt-to-assets ratio & $-0.26^{* * *}$ & $-0.21^{* * *}$ & $-0.23^{* * *}$ & $-0.19^{* * *}$ & $-0.22^{* * *}$ & $-0.25^{* * *}$ & $-0.28^{* * *}$ & $-0.26^{* * *}$ & $-0.26^{* * *}$ \\
& $(0.06)$ & $(0.06)$ & $(0.05)$ & $(0.04)$ & $(0.03)$ & $(0.04)$ & $(0.04)$ & $(0.04)$ & $(0.04)$ \\
Book-to-market ratio & $-0.19^{* * *}$ & $-0.09^{* * *}$ & $-0.04^{* * *}$ & $-0.13^{* * *}$ & $-0.11^{* * *}$ & $-0.11^{* * *}$ & $-0.10^{* * *}$ & $-0.13^{* * *}$ & $-0.05^{* *}$ \\
& $(0.04)$ & $(0.03)$ & $(0.01)$ & $(0.02)$ & $(0.04)$ & $(0.02)$ & $(0.03)$ & $(0.03)$ & $(0.02)$ \\
Sales volume & -0.01 & $-0.03^{* * *}$ & $-0.03^{* * *}$ & $-0.01^{* *}$ & $-0.01^{* *}$ & $-0.02^{* * *}$ & $-0.02^{* * *}$ & $-0.02^{* * *}$ & $-0.03^{* * * *}$ \\
& $(0.01)$ & $(0.01)$ & $(0.01)$ & $(0.01)$ & $(0.01)$ & $(0.01)$ & $(0.01)$ & $(0.01)$ & $(0.01)$ \\
Intercept & $0.36^{* * *}$ & $0.30^{* * *}$ & $0.37^{* * *}$ & $0.27^{* * *}$ & $0.32^{* * *}$ & $0.36^{* * *}$ & $0.41^{* * *}$ & $0.41^{* * *}$ & $0.45^{* * *}$ \\
& $(0.05)$ & $(0.06)$ & $(0.05)$ & $(0.04)$ & $(0.05)$ & $(0.04)$ & $(0.05)$ & $(0.05)$ & $(0.08)$ \\
Observations & 262 & 288 & 377 & 464 & 530 & 542 & 542 & 547 & 560 \\
R-squared & 0.45 & 0.41 & 0.38 & 0.37 & 0.41 & 0.41 & 0.40 & 0.38 & 0.37 \\
\hline
\end{tabular}

All specifications include industry dummies at the one-digit SIC level. Standard errors in parentheses are robust to heteroscedasticity. Significance is denoted with ${ }^{*} p<0.1,{ }^{* *} p<0.05,{ }^{* *} p<0.01$ (Two-tailed tests).

Table A4. Cross-Sectional Regression Results-OPEX.

\begin{tabular}{|c|c|c|c|c|c|c|c|c|c|}
\hline Variable & $\begin{array}{l}\text { OPEX } \\
2006\end{array}$ & $\begin{array}{l}\text { OPEX } \\
2007\end{array}$ & $\begin{array}{l}\text { OPEX } \\
2008\end{array}$ & $\begin{array}{l}\text { OPEX } \\
2009\end{array}$ & $\begin{array}{l}\text { OPEX } \\
2010\end{array}$ & $\begin{array}{l}\text { OPEX } \\
2011\end{array}$ & $\begin{array}{l}\text { OPEX } \\
2012\end{array}$ & $\begin{array}{l}\text { OPEX } \\
2013\end{array}$ & $\begin{array}{l}\text { OPEX } \\
2014\end{array}$ \\
\hline Environmental score & $\begin{array}{l}-0.35^{* * * *} \\
(0.13)\end{array}$ & $\begin{array}{l}-0.27^{* *} \\
(0.14)\end{array}$ & $\begin{array}{l}-0.39^{* * * *} \\
(0.13)\end{array}$ & $\begin{array}{l}-0.36^{* * * *} \\
(0.10)\end{array}$ & $\begin{array}{l}-0.29^{* * * *} \\
(0.10)\end{array}$ & $\begin{array}{l}-0.21 \text { ** } \\
(0.08)\end{array}$ & $\begin{array}{l}-0.24^{* * * *} \\
(0.08)\end{array}$ & $\begin{array}{l}-0.26^{* * *} \\
(0.08)\end{array}$ & $\begin{array}{l}-0.22 \text { **** } \\
(0.08)\end{array}$ \\
\hline Debt-to-assets ratio & $\begin{array}{l}-0.83^{\text {**** }} \\
(0.20)\end{array}$ & $\begin{array}{l}-0.57^{* * *} \\
(0.21)\end{array}$ & $\begin{array}{l}-0.65^{* * *} \\
(0.17)\end{array}$ & $\begin{array}{l}-0.57^{\text {**** }} \\
(0.14)\end{array}$ & $\begin{array}{l}-0.50^{* * *} \\
(0.11)\end{array}$ & $\begin{array}{l}-0.59^{* * *} \\
(0.14)\end{array}$ & $\begin{array}{l}-0.67^{* * *} \\
(0.13)\end{array}$ & $\begin{array}{l}-0.62^{\text {**** }} \\
(0.11)\end{array}$ & $\begin{array}{l}-0.62^{* * *} \\
(0.12)\end{array}$ \\
\hline Book-to-market ratio & $\begin{array}{l}-0.59^{* * *} \\
(0.16)\end{array}$ & $\begin{array}{l}-0.30 * * * \\
(0.10)\end{array}$ & $\begin{array}{l}-0.04 \\
(0.03)\end{array}$ & $\begin{array}{l}-0.14 \text { ** } \\
(0.07)\end{array}$ & $\begin{array}{l}-0.17^{* *} \\
(0.07)\end{array}$ & $\begin{array}{l}-0.08 \text { * } \\
(0.05)\end{array}$ & $\begin{array}{l}-0.09 \\
(0.06)\end{array}$ & $\begin{array}{l}-0.14^{* *} \\
(0.07)\end{array}$ & $\begin{array}{l}-0.08 * \\
(0.04)\end{array}$ \\
\hline Sales volume & $\begin{array}{l}0.21^{* * * *} \\
(0.03)\end{array}$ & $\begin{array}{l}0.18^{* * *} \\
(0.03)\end{array}$ & $\begin{array}{l}0.19^{* * *} \\
(0.03)\end{array}$ & $\begin{array}{l}0.18^{* * * *} \\
(0.02)\end{array}$ & $\begin{array}{l}0.16^{* * *} \\
(0.02)\end{array}$ & $\begin{array}{l}0.16^{* * *} \\
(0.02)\end{array}$ & $\begin{array}{l}0.14^{* * *} \\
(0.02)\end{array}$ & $\begin{array}{l}0.15^{* * *} \\
(0.03)\end{array}$ & $\begin{array}{l}0.14^{* * *} \\
(0.02)\end{array}$ \\
\hline Intercept & $\begin{array}{l}-0.85^{* * *} \\
(0.21)\end{array}$ & 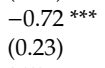 & $\begin{array}{l}-0.35 \text { * } \\
(0.20)\end{array}$ & $\begin{array}{l}-0.33^{\text {** }} \\
(0.15)\end{array}$ & $\begin{array}{l}-0.50 \text { ** } \\
(0.23)\end{array}$ & $\begin{array}{l}-0.59 \text { ** } \\
(0.26)\end{array}$ & $\begin{array}{l}-0.34 \\
(0.25)\end{array}$ & $\begin{array}{l}-0.37 \\
(0.24)\end{array}$ & $\begin{array}{l}-0.32 \\
(0.22)\end{array}$ \\
\hline Observations & 298 & 315 & 425 & 500 & 578 & 585 & 587 & 595 & 610 \\
\hline R-squared & 0.57 & 0.49 & 0.49 & 0.50 & 0.50 & 0.48 & 0.46 & 0.44 & 0.45 \\
\hline
\end{tabular}

All specifications include industry dummies at the one-digit SIC level. Standard errors in parentheses are robust to heteroscedasticity. Significance is denoted with ${ }^{*} p<0.1{ }^{* *} p<0.05,{ }^{* * *} p<0.01$ (Two-tailed tests).

Table A5. Decomposition Environmental Performance.

\begin{tabular}{lccccc}
\hline Variable: Environmental Score & Mean & S.D. & Min & Max & Observations \\
\hline Overall & 0.44 & 0.32 & 0.09 & 0.97 & $\mathrm{~N}=4493$ \\
Between & & 0.29 & 0.09 & 0.95 & $\mathrm{n}=785$ \\
Within & & 0.13 & -0.22 & 0.96 & $\mathrm{~T}-\mathrm{bar}=7.19$ \\
\hline
\end{tabular}

Table A6. Instrumental Variable Regression Results-2SLS.

\begin{tabular}{|c|c|c|c|c|c|c|}
\hline Variable & $\begin{array}{l}\text { First Stage } \\
D V=E N V\end{array}$ & $\begin{array}{l}\text { Model 1: } \\
\text { COGS }\end{array}$ & $\begin{array}{l}\text { First Stage } \\
\text { DV }=E N V\end{array}$ & $\begin{array}{l}\text { Model 2: } \\
\text { SGA }\end{array}$ & $\begin{array}{l}\text { First Stage } \\
\text { DV }=E N V\end{array}$ & $\begin{array}{l}\text { Model 3: } \\
\text { OPEX }\end{array}$ \\
\hline Environmental score & & $\begin{array}{l}-6.94^{* * *} \\
(1.90)\end{array}$ & & $\begin{array}{l}0.95^{* * *} \\
(0.29)\end{array}$ & & $\begin{array}{l}-6.06^{* * *} \\
(1.69)\end{array}$ \\
\hline Democratic leaning & $\begin{array}{l}0.01 * * * \\
(0.00)\end{array}$ & & $\begin{array}{l}0.01 * * * \\
(0.00)\end{array}$ & & $\begin{array}{l}0.01 * * * \\
(0.00)\end{array}$ & \\
\hline Debt-to-assets ratio & $\begin{array}{l}0.01 \\
(0.02)\end{array}$ & $\begin{array}{l}-0.42^{* * *} \\
(0.15)\end{array}$ & $\begin{array}{l}-0.01 \\
(0.02)\end{array}$ & $\begin{array}{l}-0.22 \text { *** } \\
(0.03)\end{array}$ & $\begin{array}{l}0.01 \\
(0.02)\end{array}$ & $\begin{array}{l}-0.63^{* * *} \\
(0.13)\end{array}$ \\
\hline Book-to-market ratio & $\begin{array}{l}-0.05^{* * *} \\
(0.01)\end{array}$ & $\begin{array}{l}-0.36^{* * *} \\
(0.12)\end{array}$ & $\begin{array}{l}-0.04^{* * *} \\
(0.01)\end{array}$ & $\begin{array}{l}-0.03 \\
(0.02)\end{array}$ & $\begin{array}{l}-0.05^{* * *} \\
(0.01)\end{array}$ & $\begin{array}{l}-0.38^{* * *} \\
(0.11)\end{array}$ \\
\hline Sales volume & $\begin{array}{l}0.13^{* * * *} \\
(0.00)\end{array}$ & $\begin{array}{l}1.03^{* * *} \\
(0.24)\end{array}$ & $\begin{array}{l}0.13^{* * *} \\
(0.00)\end{array}$ & $\begin{array}{l}-0.13^{* * *} \\
(0.04)\end{array}$ & $\begin{array}{l}0.13^{* * *} \\
(0.00)\end{array}$ & $\begin{array}{l}0.90^{* * *} \\
(0.22)\end{array}$ \\
\hline Industry controls & YES & YES & YES & YES & YES & YES \\
\hline Year dummies & YES & YES & YES & YES & YES & YES \\
\hline Observations & 4461 & 4461 & 4092 & 4092 & 4461 & 4461 \\
\hline F test (instrument, overall) & $12.97 * * *$ & $7.77^{* * *}$ & $12.91 * * *$ & $14.42 * * *$ & $12.97^{* * *}$ & $8.92^{* * *}$ \\
\hline
\end{tabular}

All specifications include industry dummies at the one-digit SIC level and year dummies. Standard errors in parentheses are robust to heteroscedasticity. Significance is denoted with ${ }^{*} p<0.1,{ }^{* *} p<0.05,{ }^{* * *} p<0.01$ (Two-tailed tests). Estimation is made with 2SLS. 
Table A7. Means, Standard Deviations, Min, Max-Election Variables.

\begin{tabular}{lllll}
\hline Variable & Mean & S.D. & Min & Max \\
\hline Lower House 2008 & 0.58 & 0.13 & 0.27 & 0.88 \\
Upper House 2008 & 0.54 & 0.16 & 0.2 & 0.88 \\
House of Representatives 2008 & 0.62 & 0.20 & 0 & 1 \\
Presidential election 2008 & 0.54 & 0.08 & 0.34 & 0.92 \\
Partisan Voter Index 2010 & 1.18 & 7.75 & -20 & 40 \\
Lower House 2011 & 0.46 & 0.14 & 0.14 & 0.77 \\
Upper House 2011 & 0.48 & 0.15 & 0.2 & 0.96 \\
House of Representatives 2012 & 0.53 & 0.26 & 0 & 1 \\
Presidential election 2012 & 0.53 & 0.08 & 0.25 & 0.91 \\
Partisan Voter Index 2014 & 1.39 & 8.32 & -22 & 40 \\
Principal component & 0.00 & 2.77 & -6.99 & 6.48 \\
\hline
\end{tabular}

For the Lower and Upper House of each state we calculate the score as members from the Democratic Party divided by the total number of members. For the House of Representatives elections, we calculate the score as seats won by democrats divided by the total number of seats of the respective state. For the presidential elections, we take the percentage votes for the Democrats as our Democratic Leaning Score. The Partisan Voter Index shows how strongly a state leans toward the Democratic or Republican Party compared to the nation.

\section{References}

1. Endrikat, J.; Guenther, E.; Hoppe, H. Making sense of conflicting empirical findings: A meta-analytic review of the relationship between corporate environmental and financial performance. Eur. Manag. J. 2014, 32, 735-751. [CrossRef]

2. Friede, G.; Busch, T.; Bassen, A. ESG and financial performance: Aggregated evidence from more than 2000 empirical studies. J. Sustain. Financ. Invest. 2015, 5, 210-233. [CrossRef]

3. Guenster, N.; Koegst, J. Environmental responsibility and firm value. In Green Crimes and Dirty Money; Spapens, T., White, R., van Uhm, D., Huisman, W., Eds.; Routledge: Abingdon, UK; New York, NY, USA, 2018; pp. 113-128. ISBN 978-0-8153-7221-9.

4. Horváthová, E. Does environmental performance affect financial performance? A meta-analysis. Ecol. Econ. 2010, 70, 52-59. [CrossRef]

5. Albertini, E. Does environmental management improve financial performance? A meta-analytical review. Organ. Environ. 2013, 26, 431-457. [CrossRef]

6. Dixon-Fowler, H.R.; Slater, D.J.; Johnson, J.L.; Ellstrand, A.E.; Romi, A.M. Beyond “Does it pay to be green?” A meta-analysis of moderators of the CEP-CFP relationship. J. Bus. Ethics 2013, 112, 353-366. [CrossRef]

7. Guenster, N.; Bauer, R.; Derwall, J.; Koedijk, K. The economic value of corporate eco-efficiency. Eur. Financ. Manag. 2011, 17, 679-704. [CrossRef]

8. Hart, S.L.; Ahuja, G. Does it pay to be green? An empirical examination of the relationship between emission reduction and firm performance. Bus. Strat. Environ. 1996, 5, 30-37. [CrossRef]

9. Horváthová, E. The impact of environmental performance on firm performance: Short-term costs and long-term benefits? Ecol. Econ. 2012, 84, 91-97. [CrossRef]

10. Jo, H.; Kim, H.; Lee, B.S.; Park, K. Corporate Environmental Responsibility and Financial Performance around the World; Working Paper, KAIST College of Business Working Paper Series; KAIST College of Business: Seoul, Korea, 2013.

11. King, A.; Lenox, M. Exploring the locus of profitable pollution reduction. Manag. Sci. 2002, 48, $289-299$. [CrossRef]

12. Russo, M.V.; Fouts, P.A. A resource-based perspective on corporate environmental performance and profitability. Acad. Manag. J. 1997, 40, 534-559. [CrossRef]

13. Hart, S.L. A natural-resource-based view of the firm. Acad. Manag. J. 1995, 20, 986-1014. [CrossRef]

14. Shrivastava, P. Ecocentric management for a risk society. Acad. Manag. Rev. 1995, 20, 118-137. [CrossRef]

15. Shrivastava, P. Environmental technologies and competitive advantage. Strat. Mgmt. J. 1995, 16, $183-200$. [CrossRef]

16. Delmas, M.A.; Pekovic, S. Environmental standards and labor productivity: Understanding the mechanisms that sustain sustainability. J. Organ. Behav. 2013, 34, 230-252. [CrossRef] 
17. Nidumolu, R.; Prahalad, C.K.; Rangaswami, M.R. Why sustainability is now the key driver of innovation. Harv. Bus. Rev. 2009, 87, 56-64.

18. Christmann, P. Effects of "Best Practices" of environmental management on cost advantage: The role of complementary assets. Acad. Manag. J. 2000, 43, 663-680. [CrossRef]

19. McKinsey Global Survey. Sustainability's Strategic Worth. Available online: http://www.mckinsey.com/ business-functions/sustainability-and-resource-productivity/our-insights/sustainabilitys-strategic-worthmckinsey-global-survey-results (accessed on 3 January 2017).

20. Klassen, R.D.; Whybark, D.C. The impact of environmental technologies on manufacturing performance. Acad. Manag. J. 1999, 42, 599-615. [CrossRef]

21. Klassen, R.D.; Whybark, D.C. Environmental Management in Operations: The Selection of Environmental Technologies. Decis. Sci. 1999, 30, 601-631. [CrossRef]

22. Shrivastava, P.; Hart, S. Greening organizations. Acad. Manag. Proc. 1992, 1992, 185-189. [CrossRef]

23. Waddock, S.A.; Graves, S.B. The corporate social performance-financial performance link. Strat. Mgmt. J. 1997, 18, 303-319. [CrossRef]

24. Di Giuli, A.; Kostovetsky, L. Are red or blue companies more likely to go green? Politics and corporate social responsibility. J. Financ. Econ. 2014, 111, 158-180. [CrossRef]

25. Wernerfelt, B. A resource-based view of the firm. Strat. Mgmt. J. 1984, 5, 171-180. [CrossRef]

26. Porter, M.; Kramer, M.R. Creating shared value. Harv. Bus. Rev. 2011, 89, 62-77.

27. Jones, D.A.; Willness, C.R.; Madey, S. Why Are Job Seekers Attracted by Corporate Social Performance? Experimental and Field Tests of Three Signal-Based Mechanisms. Acad. Manag. J. 2014, 57, 383-404. [CrossRef]

28. Wright, P.M.; Dunford, B.B.; Snell, S.A. Human resources and the resource based view of the firm. J. Manag. 2001, 27, 701-721. [CrossRef]

29. Henriques, I.; Sadorsky, P. Environmental management systems and practices: An international perspective. In Environmental Policy and Corporate Behavior; Johnstone, N., Ed.; Elgar: Cheltenham, UK; Northhampton, MA, USA, 2007; pp. 34-87. ISBN 978-1-84720-032-7.

30. Grolleau, G.; Mzoughi, N.; Thomas, A. What drives agrifood firms to register for an environmental management system? Eur. Rev. Agric. Econ. 2007, 34, 233-255. [CrossRef]

31. Ambec, S.; Lanoie, P. Does it pay to be green? A systematic overview. Acad. Manag. Perspect. 2008, $22,45-62$.

32. Darnall, N.; Edwards, D. Predicting the cost of environmental management system adoption: The role of capabilities, resources and ownership structure. Strat. Mgmt. J. 2006, 27, 301-320. [CrossRef]

33. Gupta, K. Environmental sustainability and implied cost of equity: International evidence. J. Bus. Ethics 2018, 147, 343-365. [CrossRef]

34. Ioannou, I.; Serafeim, G. What drives corporate social performance? J. Int. Bus. Stud. 2012, 43, 834-864. [CrossRef]

35. Semenova, N.; Hassel, L.G. On the validity of environmental performance metrics. J. Bus. Ethics 2015, 132, 249-258. [CrossRef]

36. Thomson Reuters. Thomson Reuters Corporate Responsibility Ratings (TRCRR): Rating and Ranking—Rules and Methodologies. Available online: https://www.refinitiv.com/content/dam/marketing/en_us/documents/ methodology/corporate-responsibility-ratings.pdf (accessed on 9 December 2016).

37. Compustat. Data Definitions. Available online: http://web.utk.edu/ \{\}prdaves/Computerhelp/COMPUSTAT/ Compustat_manuals/user_05r.pdf (accessed on 7 January 2017).

38. Bjørner, T.B.; Hansen, L.G.; Russell, C.S. Environmental labeling and consumers' choice-An empirical analysis of the effect of the Nordic Swan. J. Environ. Econ. Manag. 2004, 47, 411-434. [CrossRef]

39. Casadesus-Masanell, R.; Crooke, M.; Reinhardt, F.; Vasishth, V. Households' willingness to pay for "green" goods: Evidence from patagonia's introduction of organic cotton sportswear. J. Econ. Manag. Strategy 2009, 18, 203-233. [CrossRef]

40. Jensen, M.C. Agency costs of free cash flow, corporate finance, and takeovers. Am. Econ. Rev. 1986, 76, 323-329.

41. Hillman, A.J.; Keim, G.D. Shareholder value, stakeholder management, and social issues: What's the bottom line? Strat. Mgmt. J. 2001, 22, 125-139. [CrossRef]

42. Sarkis, J.; Cordeiro, J.J. An empirical evaluation of environmental efficiencies and firm performance: Pollution prevention versus end-of-pipe practice. Eur. J. Oper. Res. 2001, 135, 102-113. [CrossRef] 
43. Deng, X.; Kang, J.-K.; Low, B.S. Corporate social responsibility and stakeholder value maximization: Evidence from mergers. J. Financ. Econ. 2013, 110, 87-109. [CrossRef]

44. McGuire, J.B.; Sundgren, A.; Schneeweis, T. Corporate social responsibility and firm financial performance. Acad. Manag. J. 1988, 31, 854-872. [CrossRef]

45. Wooldridge, J.M. Introductory Econometrics. A Modern Approach, 7th ed.; Cengage Learning: Boston, MA, USA, 2018; ISBN 978-1-337-55886-0.

46. Rubin, A. Political views and corporate decision making: The case of corporate social responsibility. Financ. Rev. 2008, 43, 337-360. [CrossRef]

47. Stock, J.H.; Wright, J.H.; Yogo, M. A survey of weak instruments and weak identification in generalized method of moments. J. Bus. Econ. Stat. 2002, 20, 518-529. [CrossRef]

48. Fuller, W.A. Some properties of a modification of the limited information estimator. Econometrica 1977, 45, 939-953. [CrossRef]

49. Stock, J.H.; Yogo, M. Testing for weak instruments in linear IV regression. In Identification and Inference for Econometric Models: Essays in Honor of Thomas Rothenberg; Andrews, D.W.K., Stock, J.H., Eds.; Cambridge University Press: New York, NY, USA, 2005.

50. Hart, S.L.; Dowell, G. Invited editorial: A natural-resource-based view of the firm. J. Manag. 2011, 37, 1464-1479. [CrossRef]

51. Albuquerque, R.; Koskinen, Y.; Zhang, C. Corporate Social Responsibility and Firm Risk: Theory and Empirical Evidence. Manag. Sci. 2018. [CrossRef]

(C) 2019 by the authors. Licensee MDPI, Basel, Switzerland. This article is an open access article distributed under the terms and conditions of the Creative Commons Attribution (CC BY) license (http://creativecommons.org/licenses/by/4.0/). 